\title{
Optimalisasi Biofermentasi Rumen Melalui Pemberian Pakan Suplemen sebagai Upaya Peningkatan Nilai Nutrisi Jerami padi dalam Ransum Ternak Ruminansia
}

\author{
Wara Pratitis S. Suprayogi dan Susi Dwi Widyawati \\ Jurusan Peternakan, Fakultas Pertanian, Universitas Sebelas Maret \\ Jl. Ir. Sutami 36 A, Kentingan, Surakarta \\ Email: suprayogiwara@yahoo.co.id
}

\begin{abstract}
ABSTRAK
Penelitian yang bertujuan untuk mengevaluasi nilai nutrisi jerami padi melalui pemberian pakan suplemen dalam upaya optimalisasi biofermentasi rumen, telah dilakukan di Laboratorium Ilmu Nutrisi dan Makanan Ternak Fakultas Pertanian UNS dan Laboratorium Biokimia Nutrisi Fakultas Peternakan UGM. Percobaan dilakukan secara in vitro untuk mengukur fermentabilitas ransum berbahan dasar jerami padi dan percobaan in vivo dengan menggunakan 15 ekor sapi PO untuk mengetahui pengaruh pemberian pakan suplemen pada ransum basal (P0) yang terdiri atas jerami padi (90\%) dan rumput lapangan (10\%). Pada percobaan in vutro, sumber inokulum diambil dari sapi berfistula rumen dan fermentabilitas pakan diukur dengan metode in vitro gas test (Schofield, 2000). Growth Promoting Feed Supplement (GPFS) yang diberikan mengandung urea dan molases untuk mengoptimalkan sintesis protein mikrobia, bungkil kedelai (BK) dan daun lamtoro (DL) sebagai sumber protein bypass dan minyak ikan lemuru (MIL) dan daun ketepeng (DK) mengandung agensia reduksi metan. Ada 4 macam pakan suplemen yaitu BK-MIL (GPFS 1), BK-DK (GPFS 2), DL-MIL (GPFS 3) dan DL-DK (GPFS 4). Pemberian pakan suplemen sebanyak $25 \mathrm{~g} / \mathrm{kg}^{0.75}$ pada masing-masing ransum perlakuan. Adapun ransum perlakuan yang dicobakan adalah P0: ransum basal (jerami padi, 90\% dan rumput lapangan, 10\%); P1: P0 + BK-MIL; P2: P0 + BK-DK; P3: P0 + DL-MIL; dan P4: P0 + DL-DK.

Pemberian pakan suplemen sangat nyata $(\mathrm{P}<0,01)$ menurunkan produksi VFA total. Produksi VFA pada masing-masing P0, P1, P2, P3 dan P4 yaitu 62,16; 58,54; 48,32; 43,84 dan 45,26 mM. Produksi $\mathrm{C}_{2}$ berturut turut 43,86; 41,75; 33,82; 30,80 dan 30,83 mM. Produksi $\mathrm{C}_{3}$ sebesar 9,78; 8,49; 8,29; 7,40 dan 8,11 mM. Produksi $\mathrm{C}_{4}$ sebesar 8,54; 7,81; 6,22; 5,65 dan 6,32 mM. Nisbah $\mathrm{C}_{2} / \mathrm{C}_{3}$ sebesar 4,49; 4,92; 4,10; 4,17 dan 3,81. Konsentrasi $\mathrm{NH}_{3}$ sebesar 9,$25 ; 10,55 ; 10,14 ; 10,49$ dan $10,69 \mathrm{mM}$. Konsumsi ransum nyata $(\mathrm{P}<0,05)$ meningkat dengan pemberian pakan suplemen sebesar 3,65; 4,93; 5,20; 4,95 dan 4,69 kg/hari. Pertambahan bobot badan per hari yang dihasilkan oleh masing-masing ransum 0,$16 ; 0,45$; 0,$41 ; 0,20$ dan $0,27 \mathrm{~kg} /$ hari. Angka konversi pakan tidak dipengaruhi oleh pemberian pakan suplemen yaitu 23,$75 ; 11,09 ; 13,13 ; 27,81$ dan 19,41 .

Pakan suplemen dengan 4 macam formula yang berbeda mampu memperbaiki kualitas jerami padi ditinjau dari fermentabilita ransum maupun performan sapi PO yang dihasilkan. Pakan suplemen yanmg terbaik adalah pakan suplemen BK-MIL.
\end{abstract}

Kata kunci : GPFS, jerami padi, fermentabilitas, performan

\section{PENDAHULUAN}

Pemberian pakan, baik kualitas maupun kuantitas perlu diupayakan untuk memenuhi kebutuhan hidup pokok dan produksi. Pada umumnya peternak rakyat hanya memberikan pakan hijauan saja dan sering hanya berupa rumput 
lapangan. Pada musim penghujan produksi rumput ini sangan tinggi dan pada musim kemarau rumput tersebut sangat sulit mendapatkannya, sehingga pakan hijauan yang diberikan berupa jerami padi. Jerami padi merupakan limbah pertanian yang sangat tinggi produksinya sejalan dengan produksi padinya. Namun kandungan nutrien pakan ini sangat rendah diikuti dengan kualitasnya khususnya ditinjau dari nilai cernanya. Selain itu, ada beberapa hal yang perlu dicermati dalam pemanfaatan pakan jenis ini yaitu 1. mengandung proporsi dinding sel yang tinggi, 2. telah mengalami lignifikasi lanjut, 3. terdapat senyawa komplek lignoselulosa dan lignohemiselulosa yang sulit dicerna oleh mikrobia rumen, 4. mengandung kristal silikat yang mengisi ruang antar sel sehingga menyulitkan kerja enzim pencernaan, 5. kandungan Nitrogen yang rendah dengan kadar protein kasar $4.58 \%$ dan 6. kandungan vitamin dan mineral yang rendah.

Jerami padi yang telah diamoniasi dengan urea dapat dikatakan masih mempunyai nilai nutrisi yang rendah dilihat dari kemampuannya menyediakan $\mathrm{N}-\mathrm{NH}_{3}$ sebesar $57.2 \mathrm{mM}$, produksi VFA $52.2 \mathrm{mM}$, kecernaan BK 22.6\% dan degradasinya di dalam rumen pada 24 dan 48 jam masingmasing sebesar 27.6 dan $38.4 \%$ (Sutardi, 1993).

Salah satu alternatif yang dapat ditempuh untuk mengoptimalkan produksi ternak dan efisiensi nilai ekonomi pemeliharaan ternak dengan meningkatkan utilitas nutrien baik dalam rumen oleh mikrobia rumen untuk pertumbuhan dan perkembangan mikrobia maupun intestinum atau usus halus untuk memenuhi kebutuhan nutrien bagi ternak sebagai host atau induk semangnya.

Jenis pakan yang diberikan ternak ruminansia berbeda dengan ternak unggas karena ruminansia cenderung membutuhkan jenis pakan berserat hal ini berhubungan dengan lambung majemuk yang dimilikinya, khususnya di retikulorumen yang dihuni oleh berjutajuta mikrobia yang berfungsi sebagai tempat terjadinya proses pencernaan ermentative. Proses ini akan menghasilkan produk yang dimanfaatkan oleh induk semangnya, namun hal lain yang perlu dipertimbangkan adalah sebagian besar pakan yang masuk akan terdegradasi oleh mikrobia rumen sehingga ternak akan kehilangan energi pakan dalam bentuk gas metan dan panas fermentasi. Oleh sebab itu untuk meningkatkan produksi ternak dua aspek harus ditingkatkan yaitu fermentabilitas pakan dan pertumbuhan mikrobia rumen.

Mikrobia sebagai sumber pakan yang berkualitas di pasca rumen cukup memberikan kontribusi bagi pertumbuhan induk semang (host)nya. Namun optimalisasi pertumbuhan ternak masih memungkinkan untuk ditingkatkan dengan memanipulasi kondisi dalam rumen dan sentuhan teknologi pakan dalam meningkatkan efisiensi penggunaan ransum oleh ternak. Salah satu upaya yang dapat ditempuh dengan menyediakan nutrien yang dibutuhkan oleh mikrobia.

Urea dan molases merupakan perpaduan bahan pakan yang terbukti cukup efisien dalam menyediakan Nitrogen dan energi tersedia bagi mikrobia rumen. Selain itu optimalisasi biofermentasi dalam rumen juga dilakukan dengan menekan produksi gas metan sehingga akan meningkatkan efisiensi penggunaan energi ransum. Potensi minyak ikan lemuru sebagai penyedia asam lemak tak jenuh (PUFA atau Poly Unsaturated Fatty Acids) dan daun ketepeng yang mengandung kuinon dalam meningkatkan efisiensi biofermentasi rumen sebagai hydrogen synks sehingga produksi gas metan dapat ditekan. Selain dari aspek mikrobia rumen, penyediaan protein pasca rumen untuk melengkapi kebutuhan protein atau asam amino dalam proses sintesis jaringan tubuh dapat dilakukan dengan memberikan bahan pakan yang mengandung protein bypass, seperti bungkil kedelai dan daun lamtoro. Berbagai bahan pakan ini diformulasikan kedalam 4 (empat) formula pakan suplemen. 
Dari berbagai pertimbangan di atas, maka maka penelitian ini dirancang untuk mengevaluasi nilai nutrisi jerami padi dalam ransum sapi PO jantan.

\section{MATERI DAN METODE}

Penelitian ini dilaksanakan di Laboratorium Ilmu Nutrisi dan Makanan Ternak Fakultas Pertanian UNS dan Laboratorium Boikimia Nutrisi, Fakultas Peternakan UGM Yogyakarta. Percobaan in vivo dilakukan di Bekonang, Sukoharjo. Analisis proksimat bahan percobaan dikerjakan dengan metode AOAC (1980), sedangkan teknik evakuasi pakan atau ransum dengan metode gas test mengikuti metode Menke dan Steingas (1977) dalam Anonim (2004). Penelitian ini berlangsung dari bulan April sampai dengan bulan Desember 2007.
Materi penelitian yang digunakan adalah sapi berfistula rumen sebagai donor cairan rumen dalam pengujian nilai nutrisi jerami padi yang disuplementasi dengan beberapa macam pakan suplemen GPFS yang mempunyai formula yang berbedabeda.

Urea dan molase digunakan sebagai sumber $\mathrm{N}$ dan energi tersedia bagi pertumbuhan mikrobia rumen, minyak ikan lemuru dan daun ketepeng sebagai agensia reduksi metan yaitu masing-masing sebagai sumber asam lemak tak jenuh dan sumber kuinon. Bungkil kedelai yang dipananskan selama 1 jam pada suhu $100^{\circ} \mathrm{C}$ (Wodyobroto dkk., 1997) dan daun lamtoro sebagai sumber protein bypass. Adapun komposisi bahan makanan dan komposisi nutriennya disajikan pada tabel berikut.

Tabel 1. Komposisi Bahan Makanan Pakan Suplemen

\begin{tabular}{lcccc}
\hline \hline \multicolumn{1}{c}{ Pakan Suplemen } & BK-MIL & BK-DK & DL-MIL & DL-DK \\
\hline Urea & 1 & 1 & 4 & 4 \\
Molases & 5 & 5 & 20 & 20 \\
Bungkil Kedelai (BK) & 40 & 40 & 0 & 0 \\
Daun Lamtoro (DK) & 0 & 0 & 60 & 65 \\
Minyak Ikn Lemuru (MIL) & 4,3 & 0 & 4,3 & 0 \\
Daun Ketepeng (DK) & 0 & 4,8 & 0 & 4,8 \\
Bekatul & 48,7 & 48,2 & 10,7 & 5,2 \\
Vitamin dan mineral & 1 & 1 & 1 & 1 \\
\hline
\end{tabular}

Tabel 2. Kandungan Nutrien Pakan Suplemen (GPFS) yang Dicobakan

\begin{tabular}{lcccccc}
\hline \hline Pakan suplemen & $\begin{array}{c}\text { Bahan } \\
\text { kering }\end{array}$ & $\begin{array}{c}\text { Protein } \\
\text { kasar }\end{array}$ & Lemak & $\begin{array}{c}\text { Serat } \\
\text { kasar }\end{array}$ & Abu & TDN $\left.^{* *}\right)$ \\
\hline $\begin{array}{l}\text { BK-MIL (GPFS } \\
\text { 1)=P1 }\end{array}$ & 87,22 & 28,08 & 6,37 & 5,61 & 14,70 & 78,34 \\
$\begin{array}{l}\text { BK-DK (GPFS } \\
\text { 2)= P2 }\end{array}$ & 86,22 & 28,33 & 7,72 & 7,80 & 15,74 & 76,24 \\
$\begin{array}{l}\text { DL-MIL (GPFS } \\
\text { 3)= P3 }\end{array}$ & 80,23 & 27,14 & 4,75 & 9,91 & 11,23 & 70,11 \\
$\begin{array}{l}\text { DL-DK (GPFS } \\
\text { 4) P4 }\end{array}$ & 80,65 & 26,83 & 5,57 & 6,65 & 9,27 & 75,82 \\
$\begin{array}{l}\text { Rumput lapang } \\
\text { Jerami Padi }\end{array}$ & 94,47 & 12,26 & 2,22 & 16,58 & 11,92 & 61,24 \\
& 32,79 & 2,19 & 2,36 & 17,06 & 6,50 & 48,54 \\
\hline
\end{tabular}

Keterangan $:{ }^{*}$ Estimasi TDN $=59.68-1.08 \mathrm{SK}+0.3136 \mathrm{PK}+1.22 \mathrm{~L}+0.2508 \mathrm{BETN}$ (Sutardi, 1993) 
Evaluasi nilai nutrisi jerami padi dilakukan melalui pengkajian terhadap produksi VFA total dan parsial (asam asetat, asam propionat dan asam butirat), konsentrasi $\mathrm{NH}_{3}, \mathrm{pH}$ dan produksi $\mathrm{N}$ mikrobia rumen serta performan sapi PO ditinjau dari konsumsi ransum, pertambahan bobot badan dan konversi ransum.

Sumber inokulum pada percobaan ini diambil cairan rumen dari sapi berfistula rumen. Cairan rumen yang telah diambil, disaring dengan kain kasa rangkap 4 dan dimasukkan kedalam termos panas yang sebelumnya diisi dengan air bersuhu $39^{\circ} \mathrm{C}$. Pengambilan cairan rumen dilakukan pada saat sebelum sapi diberi makan pagi.

Preparasi cairan rumen. Cairan rumen dipindahkan dari termos kedalam Erlenmeyer $1000 \mathrm{ml}$ dan dijenuhkan dengan gas $\mathrm{CO}_{2}$ selama 30 menit.

Preparasi sampel. Substrat yang akan dievaluasi digiling dengan Hammer mill berukuran $1 \mathrm{~mm}$, Sampel pakan sebanyak $300 \mathrm{mg}$ yang terdiri atas $250 \mathrm{mg}$ rumput lapang dan $50 \mathrm{mg}$ masing-masing pakan suplemen dimasukkan kedalam glas syringe, atau piston pipette sampel rumput pangola sebagai pakan standar serta blanko. Selanjutnya piston pipette diolesi dengan vaselin putih dan diinkubasikan pada suhu $39^{\circ} \mathrm{C}$ dalam inkubator selama semalam sebelum diinkubasikan dalam cairan rumen untuk pengamatan. Preparasi cairan rumen dilakukan sama dengan preparasi sampel pada percobaan in vitro. Cairan rumen ini ditambahkan pada tabung yang berisi larutan buffer di atas. Selanjutnya ditambahkan pada masing-masing glas syringe yang telah berisi sampel bahan pakan, dan diinkubasikan dalam water bath suhu $39^{\circ} \mathrm{C}$ selama waktu yang telah ditentukan.

Blanko dan Standar. Setiap kali melakukan pengamatan bahan pakan yang diuji selalu disertai dengan blanko yaitu piston pipette tanpa sampel untuk mengoreksi aktivitas mikrobia rumen. Standar yaitu piston pipette yang diisi dengan bahan pakan standar yang telah diketahui nilai nutrisinya pada percobaan sebelumnya. Ini dilakukan untuk mengetahui proses fermentasi yang dikerjakan berjalan dengan baik atau tidak.

\section{Produksi Asam Lemak Atsiri} (Volatile Fatty Acids = VFA). Pengukuran produksi VFA bertujuan untuk mengetahui potensi ransum percobaan ditinjau dari fermentabilitasnya maupun kemampuannya dalam menyediakan energi bagi mikroba rumen dan induk semangnya.

Preparasi sampel. Cairan rumen hasil fermentasi ransum percobaan yang telah diinkubasikan selama 48 jam disentrifugasi dengan kecepatan $3000 \mathrm{rpm}$ selama 10 menit sebanyak $0.2 \mathrm{ml}$ ditambahkan asam metafosfat $1 \mathrm{ml}$ diinjeksikan pada Gas Kromatografi (GC = Gas Chromatography) merk Shimadzu, model GC-8A, dengan perlengkapan yang digunakan meliputi detector FID, Recorder Shimadzu, microsyringe. suhu kolom $130^{\circ} \mathrm{C}$, suhu injector atau detector $220^{\circ} \mathrm{C}$. Gas pembawa $\mathrm{N}_{2}$ dengan laju atau tekanan $1.25 \mathrm{~kg} / \mathrm{cm} 2$. Kolom yang digunakan SP-1200/1\% H3PO4, 80/100 mesh chromosorb WAW. GP10\% SP, panjang kolom $2 \mathrm{~m}$, diameter 3 $\mathrm{mm}$. Detektor FID, volume injeksi $0.5 \mathrm{ul}$. Alat ini dilengkapi dengan Integrator Shimadzu GR3A.

Prosedur kerja. Satu $\mu \mathrm{l}$ supernatant cairan rumen diinjeksikan ke dalam alat GC dengan menggunakan microsyringe. Setelah 9 menit akan tergambar pada kertas recorder luas area senyawa yang ditentukan. Sebelum sampel diinjeksikan, terlebih dahulu diinjeksikan campuran larutan asetat, propionat dan butirat standar dengan konsentrasi $0.025 \%, 0.05 \%, 03 \%$ dan $0.5 \%$. Kemudian dihitung persamaan regresi yang merupakan hubungan antara luas area asam asetat, propionat dan butirat standar (Y) dengan konsentrasi asam asetat, propionat dan butirat standar (X). Persamaan ini digunakan untuk menghitung konsentrasi asam asetat, propionat dan butirat sampel cairan rumen.

Konsentrasi amonia $\left(\mathrm{NH}_{3}\right)$. Konsentrasi amonia dalam cairan rumen 
mencerminkan kemampuan ransum dalam menyediakan Nitrogen bagi mikrobia rumen. Selain untuk tumbuh dan berkembangnya mikrobia rumen, juga untuk mengetahui aktivitas mikrobia dalam memfermentasi pakan. Metode penentuan kadar amonia menurut (Chaney and Marbach, 1962 cit Anonim, 2006).

Prosedur kerja. Satu mili Liter laurtan A (Tungstat) ditambah dengan $2 \mathrm{ml}$ cairan rumen dan $1 \mathrm{ml}$ larutan $\mathrm{B}\left(\mathrm{H}_{2} \mathrm{SO}_{4} 1 \mathrm{~N}\right)$ dingin. Sampel disentrifus pada $15.000 \mathrm{~g}$ selama 10 menit.

Tahap penentuan. Pada tabung lain diisi dengan $20 \mu \mathrm{l}$ supernatan ditambah dengan $2.5 \mathrm{ml}$ larutan $\mathrm{C}$ (phenol) dan $2.5 \mathrm{ml}$ larutan D (hypochloride) dicampur secepatnya. Selanjutnya diinkubasikan dalam waterbath $40^{\circ} \mathrm{C}$ selama 30 menit. Setelah terbentuk warna biru, dinginkan pada suhu kamar kemudian dibaca dengan Spektronik pada $\chi 630 \mathrm{~nm}$

Penentuan protein mikrobia rumen. Metode yang digunakan pada penentuan protein mikrobia rumen adalah metode Lowry. Sampel sebanyak $0.5 \mathrm{ml}$ ditambah dengan larutan Lowry B dan didiamkan selama 10 menit. Selanjutnya ditambahkan 0.25 Lowry A dan dicampur kemudian didiamkan selama 30 menit. Kemudian dibaca dengan menggunakan Spektronik pada $\chi 750 \mathrm{~nm}$.

\section{Analisis Data}

Data yang diperoleh dalam penelitian ini dianalisis dengan analisis variansi pada rancangan lingkungan yang sesuai. Untuk hasil yang berbeda dilakukan uji lanjut DMRT untuk mengetahui perbedaan antar perlakuan (Steel dan Torrie, 1989).

\section{HASIL DAN PEMBAHASAN}

Hasil akhir proses fermentasi pakan di dalam rumen adalah VFA dengan komponen utama asam asetat, propionat dan butirat. Pola fermentasi ini akan berubah apabila terjadi perubahan pakan yang diberikan pada ternak. Hal ini disebabkan karena jenis dan populasi mikrobia dalam rumen terutama bakteri dan protozoa tergantung dari pakan yang ada di dalam rumennya.

Pengukuran fermnetabilitas jerami padi dalam rumen yang diberi tambahan 4 macam pakan suplemen dengan perbedaan komposisi pakan penyusunnya telah dilakukan secara in vitro. Hasil yang diperoleh dapat dilihat pada tabel di bawah ini.

Tabel 3. Produksi VFA Total

\begin{tabular}{cccccc}
\hline \hline \multicolumn{1}{c}{ Peubah } & P-0 & P-1 & P-2 & P-3 & P-4 \\
\hline $\begin{array}{l}\text { Produksi VFA total } \\
(\mathrm{mM})\end{array}$ & $62,16^{\mathrm{C}}$ & $58,54^{\mathrm{BC}}$ & $48,32^{\mathrm{AB}}$ & $43,84^{\mathrm{A}}$ & $45,26^{\mathrm{AB}}$ \\
$\bullet$ & & & & & \\
- Asam asetat $\left(\mathrm{C}_{2}\right)$ & $43,86^{\mathrm{B}}$ & $41,75^{\mathrm{B}}$ & $33,82^{\mathrm{A}}$ & $30,80^{\mathrm{A}}$ & $30,83^{\mathrm{A}}$ \\
- Asam propionat & $9,78^{\mathrm{b}}$ & $8,49^{\mathrm{ab}}$ & $8,29^{\mathrm{a}}$ & $7,40^{\mathrm{a}}$ & $8,11^{\mathrm{a}}$ \\
$\quad \begin{array}{l}\left(\mathrm{C}_{3}\right) \\
\text { - Asam butirat } \\
\quad\left(\mathrm{C}_{4}\right)\end{array}$ & $8,54^{\mathrm{b}}$ & $7,81^{\mathrm{ab}}$ & $6,22^{\mathrm{ab}}$ & $5,65^{\mathrm{a}}$ & $6,32^{\mathrm{ab}}$ \\
Nisbah $\mathrm{C}_{2} / \mathrm{C}_{3}$ & $4,49^{\mathrm{B}}$ & $4,92^{\mathrm{C}}$ & $4,10^{\mathrm{AB}}$ & $4,17^{\mathrm{AB}}$ & $3,81^{\mathrm{A}}$ \\
\hline
\end{tabular}

Keterangan: Nilai rataan yang bertanda huruf kecil yang berbeda pada baris yang sama menunjukkan adanya perbedaan yang nyata $(\mathrm{P}<0,05)$

Nilai rataan yang bertanda huruf besar yang berbeda pada baris yang sama menunjukkan adanya perbedaan yang sangat nyata $(\mathrm{P}<0,01)$ 
Produksi VFA total sangat nyata $(\mathrm{P}<0,01)$ dipengaruhi oleh pemberian pakan suplemen dalam ransum basal hijauan campuran jerami padi dan rumput lapangan. Produksi VFA tertinggi pada ransum kontrol (P0). Pemberian pakan suplemen justru sangat nyata $(\mathrm{P}<0,01)$ menurunkan produksi VFA total. Keadaan ini dapat dijelaskan bahwa terjadi akumulasi produksi VFA pada ransum P0 karena penggunaan VFA oleh mikrobia rumen lebih rendah dibandingkan ransum perlakuan yang diterapkan. Widyobroto et al. (1999) menjelaskan bahwa penyediaan VFA dan $\mathrm{NH}_{3}$ harun bersamaan sehingga sintesis mikrobia rumen dapat berlangsung. Pada P0 diduga penyediaan sumber $\mathrm{N}\left(\mathrm{NH}_{3}\right)$ dan sumber energi (VFA) tidak terjadi secara sinkron sehingga terjadi akumulasi VFA. Hal ini didasarkan pada kenyataan bahwa kadar protein jermi padi sangat rendah $(2,19 \%)$. Jika protein jerami padi cukup fermentabel atau solubeilitasnya tinggi, keadaan inipun kemungkinan tidak dapat mendukung sintesis mikrobia rumen yang optimal. Sebagaimana dinyatakan oleh Widyawati dan Pratitis (2007) bahwa sintesis mikrobia rumen pada ransum basal hijauan berkualitas rendah seperti jerami padi sangat kecil yaitu sebesar 5,19 g/hari, sedangkan ransum tersebut jika disuplementasi, maka sintesis mikrobia rumen akan meningkat hingga 24,87 g/hari tergantung dari kualitas pakan suplemen yang diberikan. Defisiensi amonia menunjukkan tidak efisiennya sistem microbia rumen (Preston dan Leng, 1987).

Asam asetat $\left(\mathrm{C}_{2}\right)$ merupakan asam lemak rantai pendek hasil akhir fermentasi karbohidrat jenis fibrosa (berserat) oleh aksi bakteri selulolitik dan hemiselulolitik menghasilkan asam asetat pada porsi yang tinggi. Pada ransum P-0 dan P-1 menghasilkan porsi asam asetat yang sama tingginya. Hal ini menunjukkan bahwa pola fermentasi mengarah pada pembentukan asam asetat. Keadaan ini sesuai dengan nisbah $\mathrm{C}_{2} / \mathrm{C}_{3}$ yang tinggi pada ransum ini.

Walaupun porsi asam propionat mengikuti porsi asam asetat, ransum P-0 dan $\mathrm{P}-1$ lebih tinggi $(\mathrm{P}<0,05)$ dari ransum yang lain, namun tidak mengubah pola fermentasi terbukti dengan nisbah $\mathrm{C}_{2} / \mathrm{C}_{3}$ yang tetap lebih tinggi $(\mathrm{P}<0,01)$ dibandingkan ransum lain.

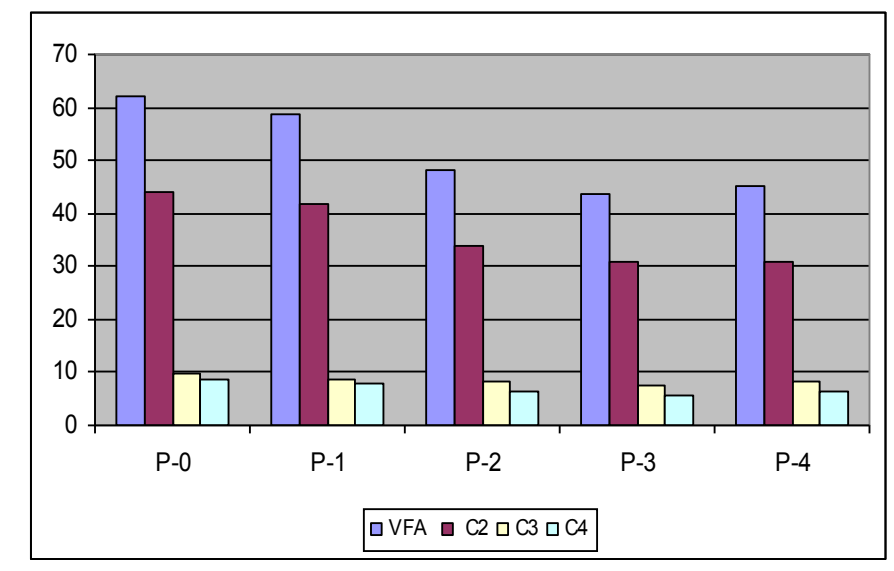

Gambar 1. Produksi VFA dan VFA Parsial Ransum Perlakuan

Asam butirat $\left(\mathrm{C}_{4}\right)$ tidak konsisten seperti $\mathrm{C}_{2}$ dan $\mathrm{C}_{3}$, pada umumnya hanya terjadi sedikit perubahan asam butirat dengan perubahan ransum yang diberikan pada ternak.
Nisbah $\mathrm{C}_{2} / \mathrm{C}_{3}$ menunjukkan pola fermentasi microbial dalam rumen berpotensi pada pembentukan asam asetat atau propionat. Nilai paling rendah dihasilkan oleh fermentasi ransum P-4 $(3,81)$, ini dapat dijelaskan bahwa ransum 
ini mempunyai kandungan bahan organik yang fermentabel lebih tinggi dibandingkan yang lainnya. Rendahnya rasio atau nisbah $\mathrm{C}_{2} / \mathrm{C}_{3}$ ini disebabkan karena tingginya bahan organik yang fermentabel memungkinkan pembentukan asam propionat lebih tinggi daripada asam asetat. Sebagaimana yang dijelaskan Sutardi (1978) bahwa pencernaan fermentatif dari karbohidrat terutama jenis pati akan menghasilkan asam laktat, asam laktat ini oleh bakteri pemakai asam laktat seperti, Propionibacterium sp, Veillonella alkalescens dan Peptostreptococcus elsdeini, akan diubah menjadi asam propionat. Selanjutnya dikatakan bahwa nisbah ini mempunyai arti penting dalam ruminologi bahwa nisbah $\mathrm{C}_{2} / \mathrm{C}_{3}$ yang rendah akan merangsang penggemukan dan cenderung pada pembentukan lemak tubuh. Pada perlakuan P-0 dan P-1 dengan nilai nisbah $\mathrm{C}_{2} / \mathrm{C}_{3}$ yang tinggi berarti pola fermentasi microbial mengarah pada pembentukan asam asetat Karena karbohidrat yang terkandung dalam ransum ini masih didominasi oleh karbohidrat fibrosa dan mikrobia yang tumbuh baik adalah jenis mikrobia selulolitik dan hemiselulolitik.

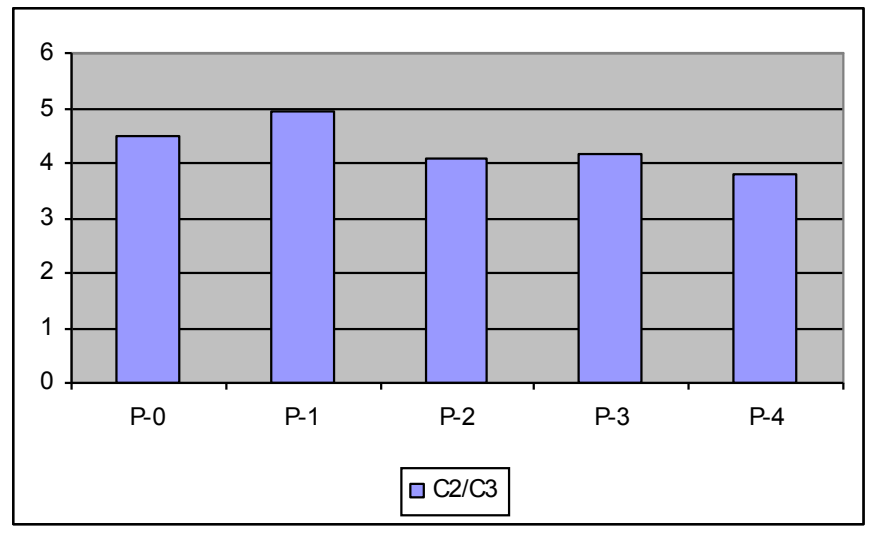

Gambar 2. Nisbah $\mathrm{C}_{2} / \mathrm{C}_{3}$ Ransum Perlakuan

Tabel 4. Kondisi Lingkungan Rumen

\begin{tabular}{lrcccc}
\hline \multicolumn{1}{c}{ Peubah } & P-0 & P-1 & P-2 & P-3 & P-4 \\
\hline $\begin{array}{l}\text { Produksi VFA total } \\
\text { (mM) }\end{array}$ & $62,16^{\mathrm{C}}$ & $58,54^{\mathrm{BC}}$ & $48,32^{\mathrm{AB}}$ & $43,84^{\mathrm{A}}$ & $45,26^{\mathrm{AB}}$ \\
Konsentrasi NH3 (mM) & $9,25^{\mathrm{a}}$ & $10,55^{\mathrm{a}}$ & $10,14^{\mathrm{a}}$ & $10,49^{\mathrm{a}}$ & $10,69^{\mathrm{a}}$ \\
pH & $6,96^{\mathrm{a}}$ & $7,10^{\mathrm{a}}$ & $7,16^{\mathrm{b}}$ & $7,03^{\mathrm{a}}$ & $7,01^{\mathrm{a}}$ \\
\hline
\end{tabular}

Keterangan: Nilai rataan yang bertanda huruf kecil yang berbeda pada baris yang sama menunjukkan adanya perbedaan yang nyata $(\mathrm{P}<0,05)$

Nilai rataan yang bertanda huruf besar yang berbeda pada baris yang sama menunjukkan adanya perbedaan yang sangat nyata $(\mathrm{P}<0,01)$

Kondisi lingkungan rumen umumnya dicerminkan dari produksi VFA sebagai hasil pencernaan fermentatif oleh mikrobia rumen. Produksi VFA merupakan hasil akhir pencernaan microbial terhadap karbohidrat. Konsentrasi amonia $\left(\mathrm{NH}_{3}\right)$ merupakan hasil akhir pencernaan fermentatif terhadap protein dan $\mathrm{pH}$ rumen menggambarkan keadaan rumen berada pada kondisi normal bagi kehidupan mikrobia.

Produksi VFA pada pakan jerami padi memperlihatkan hasil yang sangat nyata $(\mathrm{P}<0.01)$ tertinggi dibandingkan yang lainnya. Hal ini sulit dijelaskan karena dengan umur tanaman pada jerami padi memungkinkan terjadinya proses lignifikasi yang telah lanjut. Keadaan ini 
berkaitan erat dengan nilai nutrisi pakan ini terutama dilihat dari kecernaannya. Ikatan komplek lignin dan karbohidrat (selulosa dan hemiselulosa) sangat sulit dipisahlan oleh enzim yang diproduksi oleh mikrobia rumen. Beberapa teknologi pakan hijauan telah banyak dilakukan untuk merenggangkan ikatan tersebut sehingga penetrasi enzim mikrobia lebih mudah menembus ikatan tersebut.
Konsentrasi amonia berada pada kondisi yang baik bahkan konsentrasi ini cukup tinggi untuk memenuhi kebutuhan mikrobia rumen. Kebutuhan amonia bagi mikrobia rumen sebesar 3,57 sampai 7,14 mM (Satter dan Slyter, 1975; Sutardi, 1978). Dijelaskan oleh Sutardi (1979) bahwa dalam merombak protein, nampaknya mikroba rumen tidak mengenal batas.

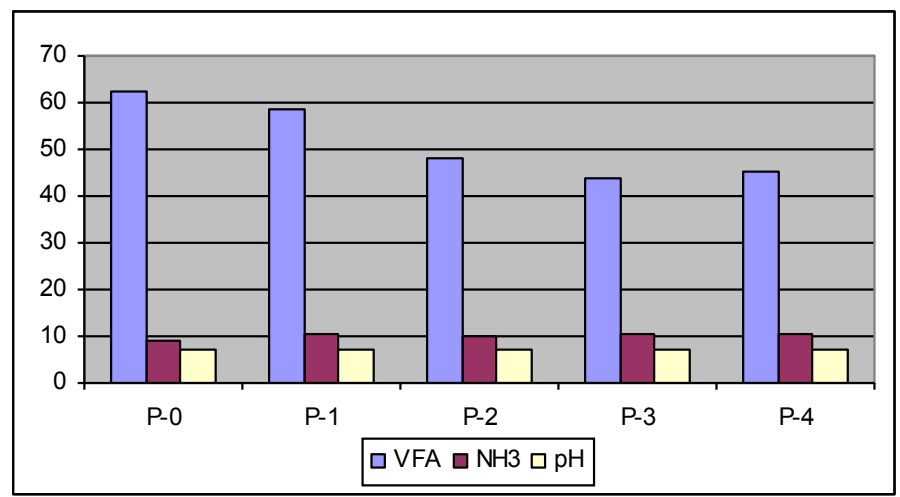

Gambar 3. Kondisi Lingkungan Rumen (Produksi VFA, Konsentrasi $\mathrm{NH}_{3}$ dan $\mathrm{pH}$ Cairan Rumen)

Selanjutnya dinyatakan bahwa perombakan itu dapat berlangsung terus walaupun amonia yang dihasilkan telah lebih dari cukup untuk memenuhi kebutuhan mikroba. Kelebihan amonia dalam rumen $(98,3 \mathrm{mg} \%)$ tidak akan meningkatkan pertumbuhan mikrobia rumen (Sutardi, 1979). Sementara Mehrez et al. (1977) menyatakan bahwa konsentrasi $\mathrm{NH}_{3}$ minimal untuk mencapai kecepatan fermentasi yang maksimal diestimasikan sebesar $235 \mathrm{mg} / \mathrm{L}$ cairan rumen.

Konsentrasi amonia yang dihasilkan pada penelitian ini tidak dipengaruhi oleh perbedaan komposisi pakan suplemen yang ditambahkan. Berkaitan dengan penjelasan di atas, memberikan gambaran bahwa protein ransum yang dikaji mempunyai nilai solubilitas yang sama.

Jerami padi merupakan pakan potensial untuk ternak ruminansia ditinjau dari aspek produksinya yang melimpah pada saat musim panen, namun dari aspek nutrisinya, jerami padi mempunyai nilai kecernaan yang sangat rendah. Berdasarkan penelitian pada sapi, nilai kecernaan BK jerami padi $(90 \%)$ dan rumput lapangan (10\%) sebesar 44.64\% (Widyawati dan Pratitis, 2007). Rendahnya nilai kecernaan ini disebabkan karena tingginya kadar lignin yang mengikat selulosa dan hemiselulosa, sehingga penetrasi enzim mikrobia sulit menembus ikatan komplek lignin-selulosa dan lignin-hemiselulosa. Selain itu, umur tanaman padi yang sudah tua saat dipanen mengakibatkan rendahnya kadar protein dalam pakan hijauan tersebut. Dari beberapa fakta yang ada menunjukkan bahwa jerami padi tidak mampu memberikan pasokan nutrien bagi ternak. Rendahnya kualitas jerami padi sebagai pakan ternak yang cukup potensial membuat para pakan dan peneliti untuk memberikan sentuhan teknologi untuk memperbaiki kualitas pakan ini, seperti amoniasi, teknologi fermentasi atau manipulasi nutrisi dalam rumen.

Pada dasarnya ternak mengkonsumsi ransum untuk memenuhi kebutuhan energinya, ketika kebutuhan energinya telah terpenuhi maka ternak akan berhenti makan. 
Erwanto (1995) menjelaskan bahwa apabila ransum tidak padat energi (tinggi serat) maka daya tampung alat pencernaan, terutama organ pencernaan fermentatif, akan menjadi faktor pembatas utama konsumsi ransum. Selanjutnya dinyatakan bahwa ternak akan berhenti makan setelah kapasitas rumennya terpenuhi, meskipun sesungguhnya masih memerlukan tambahan energi.

Tabel 5. Pengaruh Perlakuan Terhadap Konsumsi Ransum dan Performan Pertumbuhan Ternak

\begin{tabular}{llllll}
\hline \hline \multirow{2}{*}{ Peubah } & \multicolumn{5}{c}{ Perlakuan } \\
\cline { 2 - 6 } & \multicolumn{1}{c}{ P0 } & \multicolumn{1}{c}{ P1 } & \multicolumn{1}{c}{ P2 } & P3 & P4 \\
\hline Konsumsi BK, kg/hari & $3,65^{\mathrm{a}}$ & $4,93^{\mathrm{b}}$ & $5,20^{\mathrm{b}}$ & $4,95^{\mathrm{b}}$ & $4,69^{\mathrm{b}}$ \\
Konsumsi BO, kg/hari & $2,92^{\mathrm{a}}$ & $3,98^{\mathrm{b}}$ & $4,18^{\mathrm{b}}$ & $4,02^{\mathrm{b}}$ & $3,90^{\mathrm{b}}$ \\
Konsumsi PK, kg/hari & $0,27^{\mathrm{A}}$ & $0,67^{\mathrm{B}}$ & $0,73^{\mathrm{B}}$ & $0,63^{\mathrm{B}}$ & $0,60^{\mathrm{B}}$ \\
Konsumsi SK, kg/hari & 1,75 & 1,86 & 1,97 & 2,01 & 1,91 \\
PBB , kg/hari & $0,16^{\mathrm{A}}$ & $0,45^{\mathrm{B}}$ & $0,41^{\mathrm{AB}}$ & $0,20^{\mathrm{AB}}$ & $0,27^{\mathrm{AB}}$ \\
PBB/konsumsi BK, kg/kg & $0,05^{\mathrm{ab}}$ & $0,09^{\mathrm{c}}$ & $0,08^{\mathrm{bc}}$ & $0,04^{\mathrm{a}}$ & $0,06^{\mathrm{bc}}$ \\
Konversi Pakan, kg/kg & $23,75^{\mathrm{ab}}$ & $11,09^{\mathrm{a}}$ & $13,13^{\mathrm{a}}$ & $27,81^{\mathrm{b}}$ & $19,41^{\mathrm{ab}}$ \\
\hline
\end{tabular}

Keterangan : Nilai rataan yang bertanda huruf kecil yang berbeda menunjukkan adanya perbadaan yang nyata $(\mathrm{P}<0,05)$

Nilai rataan yang bertanda huruf besar yang berbeda menunjukkan adanya perbadaan yang nyata $(\mathrm{P}<0,01)$

Pemberian pakan suplemen tidak menunjukkan adanya pengaruh yang nyata $(\mathrm{P}<0,05)$ terhadap jumlah pakan yang dikonsumsi. Sapi yang mendapat perlakuan kontrol (tanpa penambahan pakan suplemen) memperlihatkan konsumsi ransum yang paling rendah $(3,65 \mathrm{~kg} /$ hari $)$. Sedangkan sapi-sapi yang mendapat tambahan pakan suplemen, jumlah ransum yang dikonsumsi nyata lebih tinggi. Sementara pakan suplemen dengan komposisi yang berbeda tidak memberikan pengaruh yang nyata terhadap jumlah ransum yang dikonsumsi. Jika dilihat dari komposisi kimia ransum perlakuan, perlakuan kontrol (P0) mengandung nutrient yang sangat rendah karena hanya terdiei atas jerami padi $(90 \%)$ dan rumput lapangan $(10 \%)$. Keadaan ini menunjukkan bahwa banyaknya ransum yang dikonsumsi oleh sapi-sapi yang mendapat pakan hijauan saja secara kuantitas telah terpenuhi sebagaimana ransum perlakuan yang lainnya. Namun dilihat dari kebutuhan nutriennya kemungkinan besar belum terpenuhi karena rendahnya kandungan nutrient jerami padi dan rumput lapangan.
Keadaan ini sesuai dengan pendapat Erwanto (1995) di atas bahwa faktor pembatas konsumsi ransum pada P0 lebih ditentukan oleh kapasitas lambung.

Pada tingkat konsumsi ransum sebesar 3,65 kg/hari kapasitas lambung sapi sudah penuh namun kebutuhan nutrien dan energinya masih berada di bawah kebutuhannya Jika dilihat dari ilustrasi di atas bahwa konsumsi bahan kering, bahan organik terjadi peningkatan secara nyata $(\mathrm{P}<0,05)$ dan peningkatan konsumsi protein yang sangat nyata $(P<0,01)$, keadaan ini menunjukkan bahwa konsumsi pada P0 dibatasi oleh kapasitas lambung sapi. Penambahan pakan suplemen memberikan kontribusi yang nyata terhadap peningkatan kebutuhan nutriennya. Sedangkan konsumsi serat kasar tidak nyata berbeda antar perlakuan, hal ini disebabkan oleh kandungan serat kasar dalam pakan suplemen sangat rendah sehingga peningkatan konsumsi asal pakan suplemen tidak memberikan pengaruh yang nyata terhadap peningkatan konsumsi serat kasarnya. 


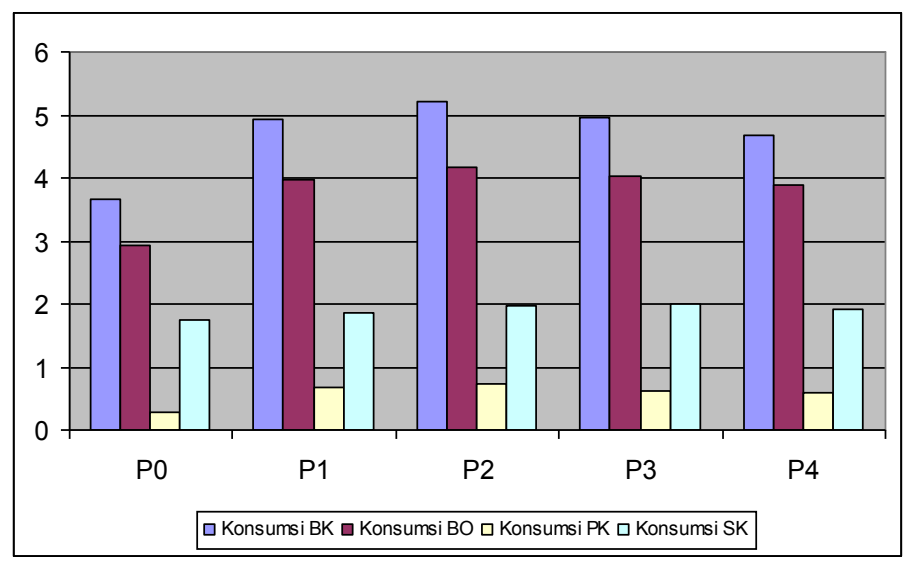

Gambar 4. Pengaruh Perlakuan terhadap Konsumsi Nutrien

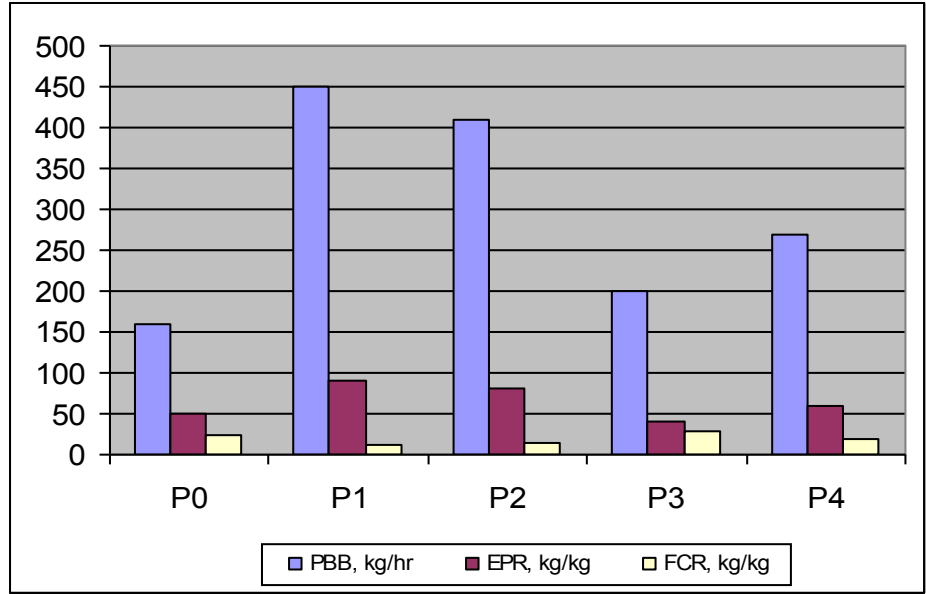

Gambar 5. Pengaruh Perlakuan terhadap Pertumbuhan Ternak

Pertumbuhan ternak dapat diukur melalui penimbangan ternak pada periode waktu tertentu. Jika satuan waktu yang digunakan satuan hari, maka sering digunakan istilah pertambahan bobot badan (PBB) perhari (Average Daily Gain = $A D G)$. Penambahan pakan suplemen dalam ransum berbahan dasar hijauan terutaman jerami padi menunjukkan adanya pengaruh yang sangat signifikan terhadap pertambahan bobot badan perharinya. Ransum kontrol memberikan PBB yang paling rendah $(0,16 \mathrm{~kg} /$ hari $)$, walaupun beberapa komposisi pakan suplemen yang ditambahkan pada P2, P3 dan P4 menunjukkan tidak adanya perbedaan yang nyata dengan ransum kontrol (P0). Ransum yang ditambahn pakan suplemen pada P1 sangat nyata $(\mathrm{P}<0,01)$ lebih tinggi dibandingkan yang lainnya. Keadaan ini menunjukkan bahwa komposisi pakan suplemen yang mengandung bungkil kedelai sebagai sumber by-pass protein kemungkinan mampu menyediakan Nitrogen pasca rumen yang dapat digunakan oleh ternak pada proses sintesis jaringan tubuh.

Sebagaimana yang dinyatakan oleh Widyobroto (1993) bahwa perlakuan pemanasan $100^{\circ} \mathrm{C}$ selama 1 jam akan meningkatkan protein yang tahan terhadap degradasi mikrobia dalam rumen namun mempunyai nilai kecernaan intestine yang tinggi. Selain itu protein asal pakan yang dirombak didalam rumen dan digunakan oleh mikrobia untuk bertumbuh dan berkembang akan menyediakan protein asal mikrobia pada proses pencernaan pasca 
rumen. Mikrobia dalam rumen merupakan material pakan sumber protein yang bernilai hayati tinggi sebesar $81 \%$ untuk bakteri dan $80 \%$ untuk protozoa (Sutardi, 1978). Selanjutnya dinyatakan bahwa sekitar $1 / 2$ sampai $2 / 3 \mathrm{~N}$ berasal dari mikrobia untuk memenuhi kebutuhan protein bagi induk semangnya (host). Dari hasil penelitian sebelumnya (Widyawati dkk., 2006) melaporkan bahwa sintesis mikrobia rumen yang ditentukan dengan dasar produksi protein mikrobia, penembahan pakan suplemen pada ransum basal rumput lapangan (P1) sebesar 2,93 $\mathrm{mg} / 100 \mathrm{ml}$, selanjutnya untuk P2, P3 dan P4 sebesar 2,96; 1,81 dan $2,58 \mathrm{mg} / 100 \mathrm{ml}$.

\section{KESIMPULAN}

Pemberian pakan suplemen pada ransum basal jerami padi $(90 \%)$ dan rumput lapangan $(10 \%)$ mampu memperbaiki mutu pakan basal ditinjau dari fermentabilitas ransum maupun perbaikan performan sapi PO. Formula pakan suplemen BK-MIL merupakan pakan suplemen yang terbaik dibandingkan yang lainnya.

\section{DAFTAR PUSTAKA}

Anonim, 2006 Petunjuk Praktikum Biokimia Nutrisi. Laboratorium Biokimia Nutrisi, Jurusan Nutrisi dan Makanan Ternak. Fakultas Peternakan, UGM. Yogyakarta.

Association of Official Analysis Chemist. 1980. Official Methods of Analysis of The Association of Official Analytical Chemist. $13^{\text {th }}$ Ed. Association of Official Analytical Chemist, Washington, DC.

Erwanto. 1995. Optimalisasi sistem fermentasi rumen melalui suplementasi sulfur, defaunasi, reduksi emisi metan dan stimulasi pertumbuhan mikroba pada ternak ruminansia. Disertasi. Program Pascasarjana. IPB, Bogor.
Mehrez, A.Z., E.R. Ørskov dan I. McDonald. 1977. Rates of rumen fermentation in relation to ammonia concentration. British. J. Nutr. 38: 437-443.

Preston, T.R. dan R.A. Leng. 1987. Matching Ruminant Production System with Available Resources in The Tropics and Subtropics. Penambul Books, Armidale. New South Wales, Australia.

Satter, L.D. dan L.L. Slyter. 1974. Effect of ammonia concentration on ruminal microbes in vitro. British. J. Nutr. 32: 199.

Schofield, P. 2000. Gas Production Methods. In: Farm Animal Metabolism and Nutrition. Edited by J.P.F. D'Mello. CABI Publishing, New York, USA.

Sutardi, T. 1978. Ikhtisar Ruminologi. Dept. Ilmu Makanan Ternak, Fakultas Peternakan. IPB, Bogor.

Sutardi, T. 1979. Ketahanan protein bahan makanan terhadap degradasi oleh mikroba rumen dan manfaatnya bagi peningkatan produktivitas ternak. Makalah dalam Seminar Penelitian dan Hasil Penelitian Penunjang Pengembangan Peternakan Tradisional. Lembaga Penelitian Peternakan, Cisarua, Bogor $5-8$ Nopember.

Widyawati, S.D. dan W. Pratitis. 2006. Perbaikan Produktivitas Ternak Ruminansia pada Peternakan Rakyat melalui Pemberian Growth Promoting Feed Supplement. Laporan Penelitian Hibah Pekerti Tahun I. Fakultas Pertanian. UNS, Surakarta.

Widyawati, S.D. dan W. Pratitis. 2007. Perbaikan Produktivitas Ternak Ruminansia pada Peternakan Rakyat melalui Pemberian Growth Promoting Feed Supplement. Laporan Penelitian Hibah Pekerti Tahun II. Fakultas Pertanian. UNS, Surakarta.

Widyobroto B.P., S. Padmowijoto, dan R. Utomo. 1997 Pendugaan kualitas protein 60 bahan pakan untuk ternak 
ruminansia. Laporan Penelitian. Fakultas Peternakan. UGM, Yogyakarta.

Widyobroto BP., SPS. Budhi, A. Agus dan B. Santosa. 1999. Effect of undegraded protein level on nutrient digestibility and microbial protein synthesis of dairy cows. In : Lobley GE, A. White and JC. MacRae. (Ed). Protein metabolism and nutrition. Book of abstracts of the VIIIth International Symposium on Protein and Metabolism. P. 72. EAAP publication Wageningen Holland. 